\title{
ADOPTION OF IMPROVED RUBBER PRODUCTION TECHNOLOGIES BY FARMERS IN AKWA IBOM STATE, NIGERIA
}

\author{
J. B. EFFIONG AND G. B. EFFIONG \\ (Received 24 July 2014; Revision Accepted 29 September 2014)
}

\begin{abstract}
This study examined the adoption of improved rubber production technologies by farmers in Akwa Ibom State, Nigeria. The specific objectives of the study are to; identify improved rubber production technologies disseminated to farmers, identify methods for disseminating information on improved rubber production technologies, determine levels of adoption of improved rubber production technologies and finally to determine effects of adoption of improved rubber production technologies on income of farmers in the study area. A simple random sampling technique was used in selecting both adopters and non-adopters of improved rubber production technologies in the study area. Primary data generated from the survey were analyzed using descriptive statistics such as percentages, frequencies, averages, paired t-test analysis and grading scale models. The result showed that about 15 different improved technologies were identified by farmers. Extension agents were found to have eight effective methods of disseminating information to farmers. The t-test analysis showed that adoption of improved rubber production technologies increased farmer's income. It was also revealed that the level of adoption of these technologies in the study area were above average, this calls for concerted effort by both researchers and extension agents to ensure adequate and timely dissemination of technologies that suit the needs and interests of the rubber farmers.
\end{abstract}

KEYWORDS: Adoption, Rubber, Improved Technologies, Akwa Ibom State.

\section{INTRODUCTION}

Adoption of innovation in agriculture expresses willingness of a farmer in accepting a change which was alien to him and practicing it because of perceived advantages in it. It represents a full-scale integration of recommended practices or innovation into on-going farm operations. It is a process because adoption of improved practices or technologies is not a single unit act. Adoption consists a series of actions which are preceded by thoughts. The adoption process is essentially a decision making process (Ekong, 2010).

Research studies in the United States of America have identified a number of stages in the process of adoption by which different researchers have claimed different stages Ekong, (2010), Roger (1995), has accepted five stages including; awareness, interest, evaluation, trial and adoption. Eze (2005) agreed with the foregoing and concluded that there are three stages namely: Awareness, Trial and Adoption, which are the most important. Adoption of innovation in agriculture manifests in increases in crops and livestock production, soil management practices and farm mechanization. However, one crucial issue which facilitates adoption process and overall integration of innovation into full scale farm operation is appropriateness of the innovation or production technologies (Ugwa and Abubakar, 2006).

Generally, in Nigeria the production of cash crop was not considered a serious problem in early $60 \mathrm{~s}$. Support was provided by government for food crops such as Cassava, Yam, Maize, Cocoyam, Plantain, Banana and Vegetables (Ejembi, et al., 2006). In recent times however, there is a growing realization that, development of cash crop production such as rubber, cocoa and oil palm can increase the capacity and productivity of the economy. For instance, the increased concentration on rubber development programmes in Akwa Ibom State led to the employment of about $20 \%$ of the youth population in the area (AKSMANR, 2011).

Natural rubber (Hevea brasiliensis) production was introduced into Nigeria from England in 1805. It is a perennial crop that is capable of being exploited for 35 years (RRIN, 2004). The plant thrives in rainforest regions of the lowland tropics with temperatures between $21-35^{\circ} \mathrm{C}$ and a well-distributed rainfall of $2,000 \mathrm{~mm}$ per year or more. Well-drained soils with a $\mathrm{pH}$ of 4.5 to 6.0 have been found suitable (RRIN, 2004).

Hevea brasiliensis takes its origin from the tropical rainforest of South America specifically from the Amazon forest in what is now Brazil. From Brazil, the first seed were transferred to Kew Garden by Sir Henry Wickham (Aigbekaen et al, 2000). According to Campbell (2000), natural rubber became popular in Europe after the invention of pheumatic tyre for bicycles and cars. The discovery of waterproof garments by Charles Macintosh in 1823 and vulcanization by Charles Goodyear laid the foundation for the development of the

J. B. Effiong, Department of Agricultural Economics/Extension, Faculty of Agriculture, Forestry and Wildlife Resources Management, University of Calabar, Calabar, Cross River State, Nigeria. G. B. Effiong, Department of Agricultural Economic and Extension, Faculty of Agriculture, University of Uyo, Uyo, Akwa Ibom State, Nigeria. 
rubber industry.

Rubber has the ability to renew its bark and ensure sustained harvest. Food and Agriculture Organization F.A.O (2003), reported that unselected, local and dry rubber have yielded $3000 \mathrm{~kg}$ to $4000 \mathrm{~kg}$ per hectare per year. Production statistics also show that Nigeria has a total of 247,100 hectares of land under rubber cultivation. Small scale farmers own 200,100 hectares while 47,000 hectares are owned by estates (Aigbekaen et al., 2000 and Schroth et a.l, 2004).

Williams and Williams (2004), suggested use of the clone improved for high productivity by introducing clone rubber trees instead of the traditional seedlings with low yield potentials. Considerable research has been conducted on natural rubber in areas of crop improvement and other production innovations.

In recent times, Federal Government of Nigeria evolved policies and programmes aimed at making the country less dependent on mineral oil, thus encouraging agricultural production. One of such government programmes is the resuscitation of moribund research institutes in the country such as the Rubber Research Institutes of Nigeria. This resulted in development of improved clones of rubber in Nigeria. Despite the innovations, it was noticed by the research institutes that the rate of adoption of these technologies by farmers have remained very low (RRIN, 2004).

Effiong, (2005) stated that small holders have a lion share of abandonment and alarming rate of decrease in hectares of land planted with rubber trees in Nigeria. The private rubber companies embarked on community development projects aimed at improving welfare of rural people of the host communities. For instance, Ndifon et. al., (2007), in a study on the corporate social responsibility functions of Rubber Industries and the felt needs for community development of its host communities in Cross River State confirmed that Rubber Industries provided employment, opportunities, rural roads, electricity and water supply to its host communities buildings equipment to town. Researches have evolved improved technologies that may increase rubber production (Ugwa and Abubakar, 2006) It is true that rubber production is contributing about $40.0 \%$ to the present day Nigerian economy (RRIN, 2004). The establishment of the Rubber Research Institute of Nigeria (RRIN) was aimed at overcoming the problems facing rubber production technologies in Nigeria (Udom, 2006). The Institute has led to the development of improved technologies for rubber production. Efforts have been made to disseminate these technologies to farmers by RRIN agents and similar agencies in Nigeria, (Eskekhede et al, 2006).

Several adoption awareness had been made over the years by Rubber Research institutes and organizations to enlighten farmers on the benefits of adoption of improved rubber production technologies including employment generation and income. It is not expected of farmers to hesitate the adoption (RRIN, 2004). Yet farmers to some extent have exhibited a cautious attitude towards adoption of improved rubber production technologies. This study therefore seeks to reawake the interests of rubber farmers in adoption of improved production technologies.
Objectives of the Study

The general objective of the study is to analyse the adoption of improved rubber production technologies by farmers in Akwa Ibom State.

\section{The specific objectives of the study are to;}

i. identify improved rubber production technologies disseminated to farmers in the study area,

ii. identify methods for disseminating information on improved rubber production technologies in the study area,

iii. determine levels of adoption of improved rubber production technologies in the study area,

iv. determine effects of the adoption of improved rubber production technologies on income of farmers in the study area.

\section{Research Hypotheses}

To achieve the objectives of this study, the hypothesis stated in the null was tested.

Ho: Adoption of improved rubber production technologies has no significant effect on farmers' income.

\section{METHODOLOGY}

This study was conducted in Akwa Ibom State, Nigeria. Akwa Ibom State was created on $23^{\text {rd }}$ September, 1987, out of the old Cross River State. The State is located in the southern geographical zone of Nigeria and predominantly populated by the Ibibios, Annang and Oron (AKSMANR, 2011). Akwa Ibom State lies between Longitudes $4^{0} 32^{1}$ and $8^{0} 25^{1}$ East of the equator and Latitudes $4^{0} 32^{1}$ and $5^{0} 31^{1}$ North of the Greenwich Meridian. The state is located in the forest belt of Nigeria. The State has 31 Local Government Areas with 6 agricultural zones namely; Abak Ikot Ekpene, Oron, Eket, Etinan and Uyo. It has 3 Senatorial Districts namely Uyo, Eket and Ikot Ekpene. The climate is tropical rain forest marked by two distinct seasons, the dry (November, April) and the wet (May -October) seasons. It has an average annual rainfall and temperature of $2500 \mathrm{~mm}-3000 \mathrm{mmm}$ and $20^{\circ} \mathrm{C}$ to $30^{\circ} \mathrm{C}$ respectively. Mean relative humidity is about $80.0 \%$ (AKSMANR, 2011). The soil found in the area is generally fertile sandy loam. The area is suitable for cultivation of many food and cash crops such as maize, cassava, oil palm, rubber and cocoa among others.

Six Local Government Areas were covered in the study namely Uyo, Itu, Onna, Ikot Ekpene, Etinan and Nsit Atai. List of farmers were obtained from the respective block extension agents. A simple random sampling technique was used to select one hundred and ninety-two (192) farmers interviewed in the study. Data used were from primary sources collected through a well structured questionnaire.

\section{Analytical Technique}

Objectives I \& ii were analyzed using descriptive statistics like percentages, means and frequency tables. Objective (iii) was realized using a seven point grading scale. Objective (vi) was analyzed using paired 
treatment test. The data for objective (iv) was obtained using questions structured on a seven point grading scale; Unaware (O), Aware (1), Interest (2), Evaluation (3), Trial (4), Accept (5) and reject (6).

The mean adoption level was determined thus:

Where

$$
\text { Mean Score }(\bar{X})=\sum f \frac{x}{n}
$$

$$
\begin{array}{rll}
\bar{X} & = & \text { Mean Score } \\
\varepsilon & = & \text { Summation } \\
\mathrm{f} & = & \text { Frequency } \\
\mathrm{x} & = & \text { Likert Nominal Score } \\
\mathrm{n} & = & \text { Number of respondents } \\
\bar{X} & = & \frac{0+1+2+3+4+5+6}{7} \\
& & \\
& & \frac{21}{7}=3.0
\end{array}
$$

Respondents with awareness score of 3.0 and above were considered to adopt improved rubber production technologies disseminated.

\section{Model Specification}

A paired treatment test was used to determine the effects of the adoption of improved rubber production technologies on income of farmers in the study area. This is implicitly stated according to Emerole (2013) as follows:

$$
t=\frac{\bar{X}_{1}-\bar{X}_{2}}{\sqrt{\frac{s_{1}^{2}}{n_{1}}+\frac{s_{2}^{2}}{n_{2}}}}
$$

$\mathrm{n}_{1}+\mathrm{n}_{2}-2$ degrees of freedom
Where $\bar{X}_{1}=$ Mean income of adopting farmers

$\bar{X}_{2}=$ Mean income of non-adopting farmers

$\mathrm{S}_{1}=$ Variance of income of adopting farmers.

$\mathrm{S}_{2}=$ Variance of Income of Non-adopting farmers

$\mathrm{n}_{1}=$ Sample Size for adopting farmers.

$\mathrm{n}_{2}=$ Sample Size for Non-adopting farmers.

The model is however expected to address the effects of adoption of improved rubber production technologies on farmers in Akwa Ibom State.

\section{RESULTS AND DISCUSSION}

\section{Distribution of Farmers According to the Disseminated Improved Rubber Production Technologies by Extension Agents}

The distribution of the respondents according to the disseminated improved rubber production technologies is shown in Table 1. The table shows that rubber farmers response to improved rubber production technologies extended to them in varying degrees. These responses show that farmers are familiar with some of these technologies. For example snail farming, $(98.96 \%)$, use of agrochemicals $(96.88 \%)$, recommended planting space $(96.88 \%)$, recommended pest and disease control measure (94.27\%), RRIN600 $(90.10 \%)$, recommended planting time $(88.02 \%)$, intercropping with food crops $(84.89 \%)$. But they are yet to settle for a few others like recommended fertilizer type and dosage (43.23\%) and NIG 801 (44.79\%). This could be because these technologies have just been extended to them (RRIN, 2006).

Table 1: Distribution of Rubber Farmers according to Disseminated improved Rubber Production Technologies by

\begin{tabular}{llll}
\multicolumn{3}{c}{ Extension Agents } & \\
\hline S/N & Improved Technology & $\begin{array}{l}\text { Frequency } \\
(\mathbf{n = 1 9 2 )}\end{array}$ & Percentage (\%) \\
\hline 1. & Snail farming & 190 & 98.96 \\
2. & Use of Agrochemicals & 186 & 96.88 \\
3. & $\begin{array}{l}\text { Recommended planting space } \\
\text { Recommended Pest and Disease }\end{array}$ & 186 & 96.88 \\
& Rentrol & 181 & 94.27 \\
5. & Measures & 169 & 88.02 \\
6. & Recommended Planting time & 163 & 84.89 \\
7. & Intercrop with food crops & 159 & 82.81 \\
8. & Use of Ethylene to stimulate rubber yield & 157 & 81.77 \\
9. & Recommended Taping time & 100 & 52.08 \\
10. & Improved Tapping Technique & 83 & 43.23 \\
11. & Recommended fertilizer type and dosage & & \\
& Improved materials & 173 & 90.10 \\
& Use of RRIN 600 & 113 & 58.85 \\
& Use of RRIN 500 & 111 & 57.81 \\
& Use of NIG 805 & 86 & 44.79 \\
& Use of NIG 801 & 106 & 55.21 \\
\hline
\end{tabular}

Source: Field Survey Data, 2013

* Multiple Responses recorded 
Methods of Disseminating Information on Improved Rubber Production Technologies in the Study Area

The distribution of respondents according to reported methods of disseminating information on improved rubber production technologies in the study area is presented in Table 2. It shows that farm and home visits (89.0\%) method demonstration $(94.0 \%)$, radio $(88.0 \%)$, Result demonstration (87.0\%) Opinion Leaders (83.0\%), Talk shows (78.0\%), Posters/Hand Bills (76.0\%), Telephone Calls (70.0\%) and text messages (53\%) among others were the methods of information dissemination widely used by extension agents in Akwa Ibom State. Methods like television (10.0\%), magazines $(16.0 \%)$, Newspapers $(20.0 \%)$, and film/slide shows $(24.0 \%)$ were scarcely used by extension agents in disseminating information on improved rubber production technologies. This finding is in agreement with Agwu and Abubakar (2009), which stated that method demonstration is the most effective method of technology and information dissemination on improved agricultural technologies among farmers.

Table 2: Distribution of Rubber Farmers according to Responses on Method of Information Dissemination

\begin{tabular}{llll}
\hline S/N & Method Used & $\begin{array}{l}\text { Frequency } \\
\mathbf{n}_{=192}\end{array}$ & Percentage \\
\hline 1. & Method demonstration & 180 & 94.0 \\
2. & Farm/Home Visits & 170 & 89.0 \\
3. & Radio & 169 & 88.0 \\
4. & Result demonstration & 168 & 87.0 \\
5. & Opinion Leaders & 158 & 83.0 \\
6. & Talk Shows & 148 & 78.0 \\
7. & Posters/Hand Bills & 146 & 76.0 \\
8. & Telephone Calls & 134 & 70.0 \\
9. & Text Messages & 101 & 53.0 \\
10. & Film/Slide Presentation & 46 & 24.0 \\
11. & Exhibition & 43 & 23.0 \\
12. & Newspapers & 38 & 20.0 \\
13. & Extension Bulletin & 36 & 19.0 \\
14. & Magazine & 31 & 16.0 \\
15. & Television $\quad$ Source: Field Survey Data, 2013 \\
\hline \multicolumn{4}{c}{${ }^{*}$ Multiple Responses recorded. } \\
\end{tabular}

Determination of the level of Adoption of Improved Rubber Production Technologies in the Study Area

The distribution of farmers according to level of adoption of improved rubber production technologies is shown in Table 3. The table shows that improve planting materials RRIN 500 had adoption mean scores of $\bar{X} 4.42$ and ranked the highest. Also, use of Agrochemicals, Recommended tapping time, improved materials RRIN 600 , Use of Ethylene and recommended planting space recorded mean score of $\overline{\mathrm{X}} 4.33, \overline{\mathrm{X}} 4.0, \overline{\mathrm{X}} 3.98, \overline{\mathrm{X}} 3.92$ and $\overline{\mathrm{X}} 3.90$ respectively. Furthermore, the Table reveals that Akwa Ibom State rubber farmers had adoption mean scores of $\overline{\mathrm{X}} 3.79$ and $\overline{\mathrm{X}} 3.71$ for intercropping with food crops and improved planting materials NIG801 respectively. Improved planting materials NIG800 had mean scores of $\bar{X} 3.70$ ranked 9 , recommended pest and disease control $\overline{\mathrm{X}} 3.50$ ranked 10 , NIG805 had $\overline{\mathrm{X}} 3.43$, ranked 12 while snail farming technology had adoption mean score of $\bar{X} 3.20$, ranked 13. However, the adoption level of recommended fertilizer type and dosage was low with mean score of $(\overline{\mathrm{X}} 2.10)$ ranked the least in the study.

The mean score for the total rubber production technology package in the state indicates that it is greater than the grading critical score of 3.0. This implies that adoption of improved rubber production technology was high. Could be farmers were already using these technologies, especially improved planting materials. This agrees with the research findings of Okonade et al., (2005) and Nwaobiala C. U. (2012) that $90 \%$ of the rural farmers rely on agricultural information from extension agents. 
Table 3: Estimates of the level of Adoption of Improved Rubber Production Technology

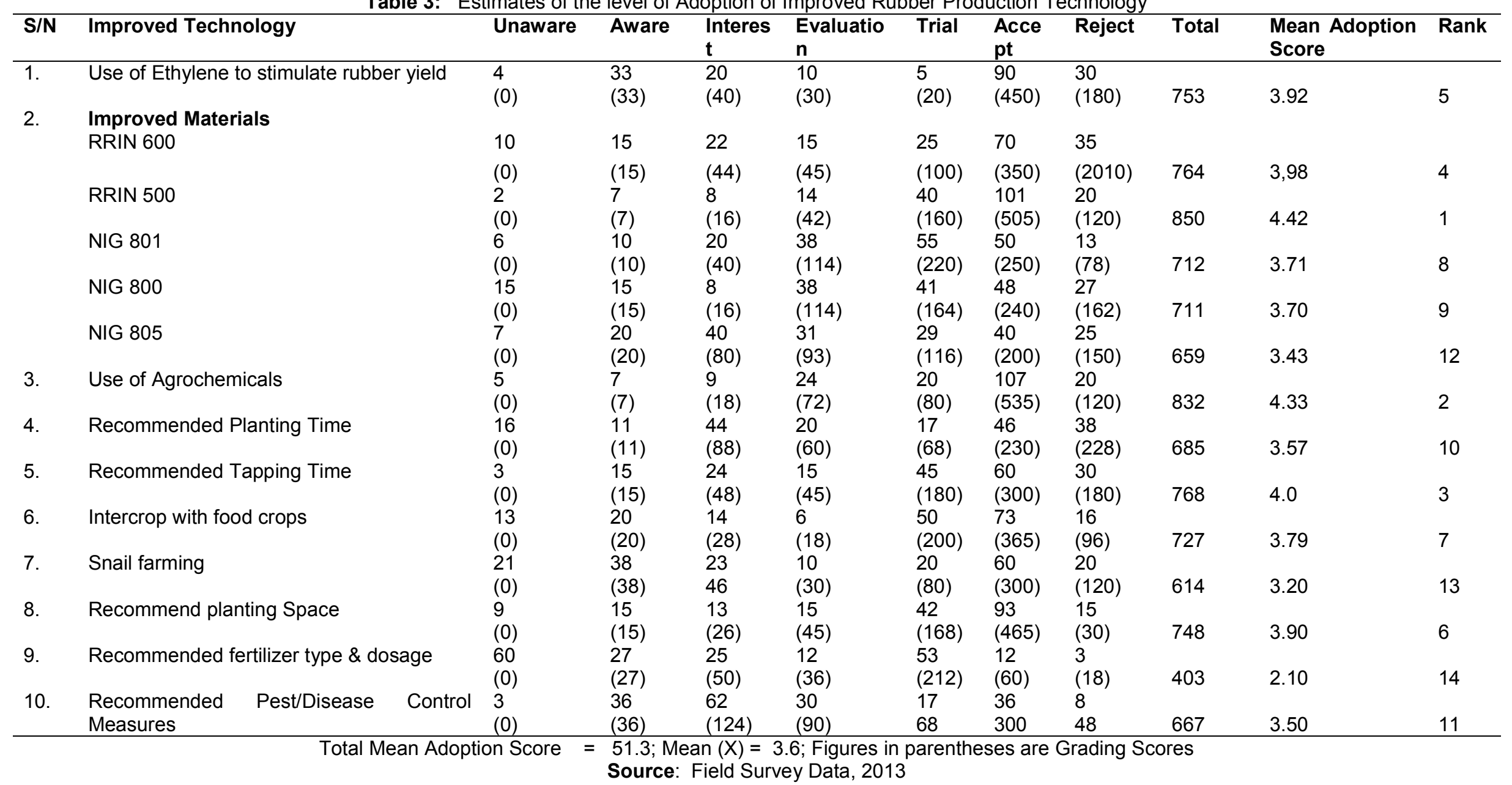


Effect of the Adoption of Improved Rubber Production Technologies on Income of Farmers in Akwa Ibom State

The result of the analysis as shown in Table 4 reveals that the mean farm size of adopters farm was 1.165 hectares, while that of the non-adopters farm was 0.741 hectares. The difference in mean farm size between the two group of farmers was 0.424 hectares. The result shows that the calculated "t" is 5.810 which was greater than the tabulated " $\mathrm{t}$ " of 2.581 and is highly significant at $1.00 \%$ level of probability. This result reveals that improved rubber adopters expanded their plantations using improved rubber varieties. Udom (2009) asserted that large farm size is as a result of increased farm outputs ploughed into the farm business.

The result of the difference in inputs used by both farmers in the state were statistically compared in Table 4. The result shows that the mean inputs used by adopter farmers were $4245.054 \mathrm{~kg}$, while the nonadopter farmers had a mean of $3024.943 \mathrm{~kg}$. The mean difference of inputs of the two groups of farmers was
$1220.111 \mathrm{~kg}$. The result indicates that calculated "t" of 1.871 , which was greater than tabulated " $t$ " of 1.63 is significant at $10.00 \%$ level of probability. This shows that the adopter farmers used improved inputs (improved materials and Agrochemicals among others). Foster (2003) stated that the size of any farm is determined by the quality and quantity of inputs used in such farms.

The effect of adoption of improved rubber production technologies on income of farmers in the study area were also analyzed in Table 4. The table shows that the mean annual income of the Adopters of rubber production technologies was $\$ 309,500.00$ while

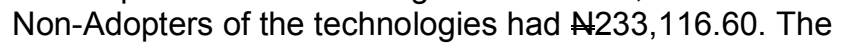
mean difference between the two farmers is $\$ 76,383.40$. The result showed that the calculated " $t$ " was 6.670 which is greater than the tabulated "t" of 2.59 and was highly significant at $1.00 \%$ level of probability. This implies that adoption of improved rubber production technologies led to increased income of farmers. This agrees with the work of Onunka (2005), who discovered that adoption of improved striga tolerant maize varieties enhanced yield and income of farmers.

Table 4: Effect of Adoption of Improved Rubber Production Technologies on Farmer's Income in the Study Area

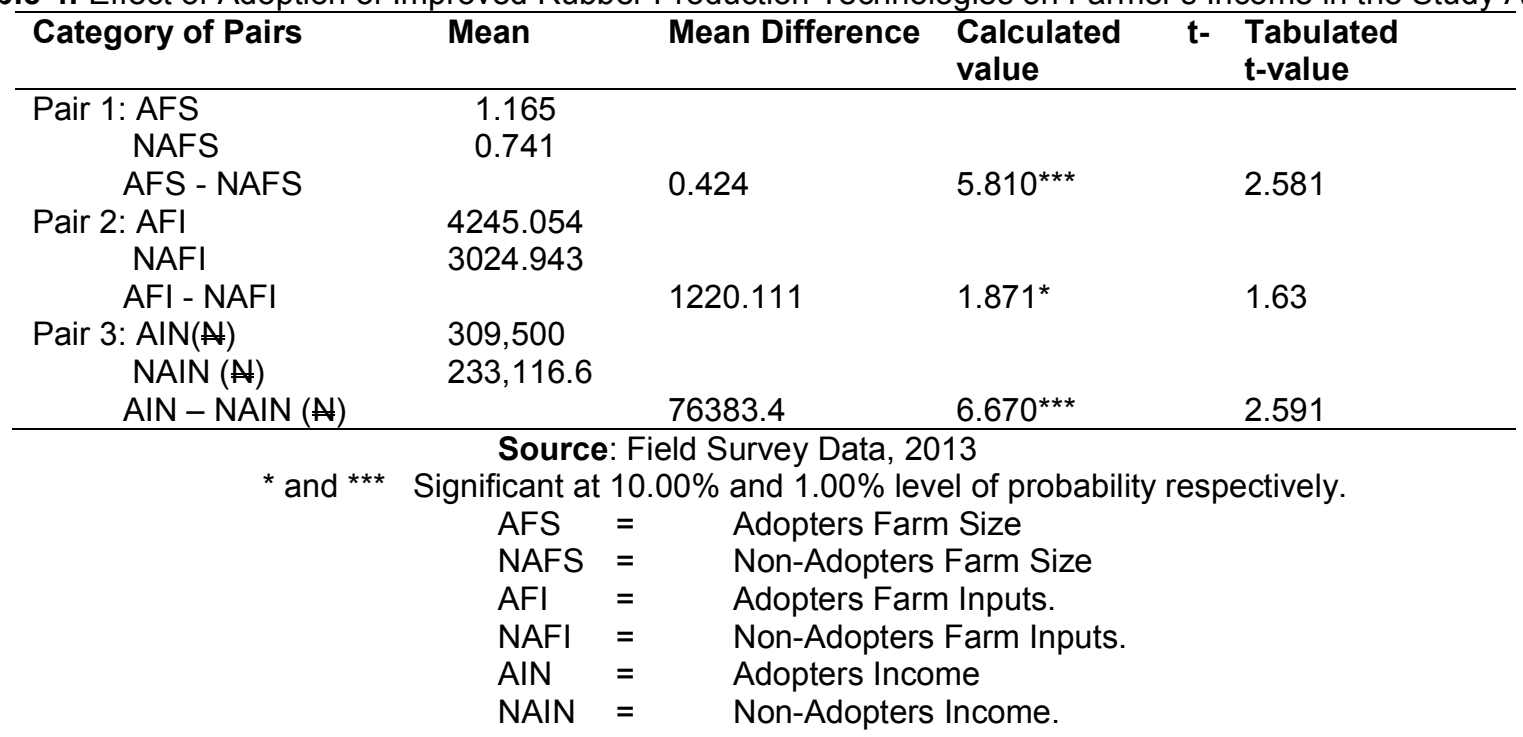

\section{CONCLUSION}

The result of the multiple responses to improved rubber production technologies disseminated to rubber farmers in Akwa lbom State revealed that the farmers were familiar with snail farming $(98.96 \%)$, use of agrochemicals $(96.88 \%)$, recommended planting space (96.88\%), recommended pest and disease control measure $(94.27 \%)$, RRIN600 $(90.10 \%)$, recommended planting time (88.02\%) and intercropping with food crops $(84.89 \%)$. They are yet to settle for a few others like recommended fertilizer type and dosage $(43.23 \%)$ and NIG $801(94.79 \%)$. The result of method of information dissemination for adoption of improved rubber production technologies by Akwa Ibom rubber farmers showed that farmers preferred farm and home visits
$(89.0 \%)$, method demonstration $(94.0 \%)$, radio $(88.0 \%)$, result demonstration (87.0\%), opinion leaders, $(83.0 \%)$, Talk shows $(78.0 \%)$, Posters/handbills (76.0\%), Telephone Calls $(70.0 \%)$ while methods like television $(10.0 \%)$, Magazines (16.0\%), Newspapers $(20.0 \% 0$ were scarcely used.

Furthermore, the result of the level of adoption of improved rubber production technologies among Akwa Ibom rubber farmers using 7-point grading scale showed adoption of technologies such as use of improved materials RRIN500 ( $\bar{X} 4.42)$, use of Agro-chemical

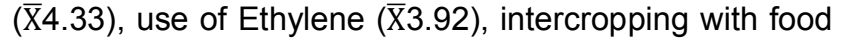

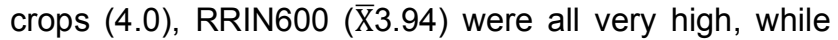
recommended pest and diseases control was ranked the least with $(\overline{\mathrm{X}} 2.10)$. The result of the paired t-test analysis on the effect of adoption of improved rubber production 
technologies showed that annual income of adopters of improved rubber technologies $\$ 309,500.00$ were significantly higher than tat of the non-adopters of improved rubber production technologies $\$ 233,116.00$. Adoption was significant at $1.00 \%$ level of probability for the rubber farmers in the state.

This study revealed that improved rubber production technologies were not fully adopted by rubber farmers. The reasons as shown in the study is the low level of adoption which was a little above average. The enterprise however was highly profitable and holds a strong prospect for household income generation, export and youth empowerment if adoption is enhanced. Rubber production has also been identified as one enterprise with great potentials which can greatly impact on poverty reduction, and the general economy of the nation.

\section{REFERENCES}

Agwu, A. E., 2004. Factors influencing adoption of improved cowpea production technologies in Nigeria. Journal of International Agricultural and Extension Education, 2, (1): 81-88.

Agwu, A. E and Abubakar., 2009. Sources of Agricultural Information Used by Arable Crop Farmers in Isale Osun Farm Settlement, Osogbo L.G.A. Journal of Agricultural Extension, 13, (1): 7-11.

Aigbekaen, E. O., Imorhagbe, E. O and Omokhafe, K. O., 2000. "Adoption Behaviours of Peasant Farmers with regard to Improved Cropping System: A case study of Northern Nigeria" in Improved Agricultural technologies for small scale Nigeria farmers. Proceeding of the National Farming System Research Network held in Jos Plateau State, Nigeria, May Workshop 10-13.

Akwa Ibom State Ministry of Agriculture and Natural Resources (AKSMANR)., 2011. Annual Reports, Akwa Ibom State Government Press, 8-10.

Apu, U., 2004. Adoption of Two Improved Cassava Varieties TMS 30572 and NR8082 by Farmers in Ohafia Agriculture Zone of Abia State, Nigeria. M.Sc. Thesis Department of Rural Sociology and Extension, Michael Okpara University of Agriculture, Umudike, pp. 12-14.

Campbell, M. J., 2000. New Technology Rural Development, the Social Impact. Routledge Press, London, 5-6.

Effiong, E. O., 2005. "Efficiency of Production in selected livestock enterprises in Akwa Ibom State. Unpublished Ph.D Dissertation, Dept. of Agric. Economics, MOUA, Umudike, pp.51-54.

Ejembi, E. P., Omoregbee F. E and Ejembi, S. A., 2006. Farmer's Assessment of the Training and visit Extension system in Central Nigeria. Evidence from Barkini Ladi, Plateau State. Journal of Social Science 12, (3): $207-212$.

Ekong, E. E., 2010. An Introduction to Rural Sociology. Third Edition, Dove Educational Publishers, Uyo, Nigeria.

Emerole, C. O., 2013. "Statistical Methods in Socioeconomic Research a learner's self study companion". Viewpoint Digital Prints, Umuahia, Abia State, 147-149.

Eskekhede, T. U., Ugwa, I. K and Aigbekaen, E. O., 2006. "Suitability and Economic viability of intercropping in Rubber on Acid Sandy soils of Southern Nigeria". India Journal of Natural Rubber Resource, 9, (1): 36-39.

Eze, S. O., 2005. "Diffusion and adoption of Innovation". In Nwachukwu, I. and Onuekusi, G. (2005). Agricultural Extension and Rural Sociology. Snap press Ltd. Enugu, pp. 249-259.

Food and Agriculture Organization (FAO)., 2003. "Rubber production in Nigeria the Potential for Industrial Development. Rome Italy, 40.

Foster, G. M., 2003. "Traditional culture and the impact of Technological Change". Harper Press, New York.

Ndifon, H. M., Echua, R. O and Nrar, N. M., 2007. Corporate social responsibility and community development. A case study of PAMOL (Nig.) Rubber Estate, Cross River State, Nigeria. The Social Sciences Journal. 3, (2): 14-18.

Nwaobiala, C. U., 2012. "Appraisal of Farmers participation in IFAD/FGN/NDDC CommunityBased Natural Resource Management Programme in Abia and Cross River States, Nigeria". Unpublished Ph.D Thesis submitted to Department of Agric-Econs and Extension, Absu, Nigeria.

Onunka, B. N., 2005. A survey of the Adoption of Sweet Potato (Ipomea batata) Production Technologies in Abia State. Unpublished M.Sc. Thesis of Agric. Econs. and Extension Department, ABSU Nigeria.

Rogers, E. M., 1995. "Diffusion of innovation". $6^{\text {th }}$ ed. New York: Free press.

Rubber Research Institute of Nigeria (RRIN)., 2004. "Report on survey of Agro Raw materials in Nigeria". A monograph produce by Rubber Research Institute of Nigeria, 3-6.

Rubber Research Institute of Nigeria (RRIN)., 2004. "Rubber Production in Nigeria": A monograph published by Rubber Research Institute of Nigeria. pp. 13-16. 
Schroth, G., Moraes, U. H. F and Da Mota, M. S. S., 2004. "Increasing the profitability of traditionally planted rubber agro-forest at Tapojo's River, Brazilian Amazon". Journal of Agric. Ecosystem and Environment, 102: 319-339.

Udom, E. R., 2006. "Problems of Agricultural Development in Nigeria, our Collective Amnesia". A paper presented at the Annual Conference of the Rectors of the Colleges of Agriculture held at the Michael Okpara College of Agriculture, Umuagwo, Imo State, September 2006, 71-72.

Udom, F. A., 2009. Adoption of Selected Crop Based Technologies by Crop Farmers in Akwa Ibom State, Nigeria. M.Sc. Thesis Department of Rural Sociology and Extension, Michael Okpara University of Agriculture, Umudike.
Ugwa, I. K and Abubakar, M., 2006. "Evaluation of the Adoption of Improved Rubber Farmers in MidWestern Nigeria". Journal of Sustainable tropical Agricultural Resources, 1(7), pp 86-90.

Williams, C. E and Williams, S. K. T., 2004. "Agricultural User population and their information needs. A case study of Badeku Pilot Rural Development Project in Nigeria". Proceedings of CAB's Scientific Conference, Arusha, Tanzania, February. Pp. 156-160. 